\title{
Sistem Kendali dan Monitoring dengan Syaraf Tiruan pada Pembangkit Listrik Tenaga Surya
}

\author{
Abdul Haris ${ }^{1}$; Hengki Sikumbang ${ }^{2}$; Muhammad Jafar Elly \\ 1, 2, 3 Institut Teknologi PLN \\ ${ }^{1}$ harismwakang@itpln.ac.id \\ 2hengki@itpln.ac.id \\ 3jafar.elly@itpln.ac.id
}

\begin{abstract}
Solar Power Plant condition has not optimal due to the position of the solar cells in generator is still static so that the light absorption has not spread evenly. Although Hybrid technology is now available, but it cannot be optimized properly and still cannot be implemented especially in a small scale and in remote areas. Another problem that needs attention is the continuity of the operation of installed Solar Power Plants (SPPS), considering the installation and maintenance of the plant requires high investment costs because the installation of solar panels requires a large amount of land and costs. Moreover, it requires a qualified technician to handle the problems and monitor plant conditions quickly and accurately. From the problem description, the first step is to identify the technology used in the factory, the second is the need to design a new system to be able to solve important problems in the plant, and the third is to build a computerized system using the Hybrid Method on the plant used which is a combination of Artificial Intelligence and Data Mining processes so that it can present accurate data. Therefore, it can help and analyze plant performance, monitor, and control remote plants quickly using Web Control.
\end{abstract}

Keywords: Solar power plants; Hybrid method; Web Control

\begin{abstract}
ABSTRAK
Permasalahan kondisi Pembangkit Listrik Tenaga Surya masih belum optimal dikarenakan posisi solar cell pada pembangkit masih statis sehingga dalam penyerapan sinar masih belum merata. Sekalipun teknologi Hybrid sekarang sudah ada namun belum dapat dioptimalkan dengan baik dan masih belum dapat diimplementasikan terlebih diskala kecil dan di daerah terpencil. Masalah lain yang perlu mendapatkan perhatian adalah pada keberlanjutan operasi dari pembangkit listrik tenaga surya (PLTS) yang telah terpasang, mengingat instalasi dan perawatan pembangkit tersebut memerlukan biaya investasi yang cukup tinggi dikarenakan instalasi panel surya membutuhkan lahan dan biaya yang besar. Selain itu juga membutuhkan tenaga teknis yang mumpuni dalam penanganan masalah serta pemantauan kondisi pembangkit diperlukan secara cepat dan tepat. Dari uraian masalah tersebut maka langkah Pertama adalah perlu dilakukan identifikasi teknologi yang digunakan pada pembangkit, Kedua adalah perlu melakukan desain sistem baru untuk dapat menyelasaikan masalah-masalah yang krusial pada pembangkit dan yang Ketiga adalah perlu dibangun sistem yang terkomputerisasi yang menggunakan Metode Hybrid pada pembangkit yang merupakan gabungan Artificial Intelligence dan Proses Data Mining sehingga mampu menyajikan data yang akurat sehingga dapat membantu dan menganalisa kinerja pembangkit, memantau dan mengendalikan pambangkit dalam jarak yang jauh secara cepat dengan menggunakan Web Control.
\end{abstract}

Kata kunci: PLTS; Metode Hybrid; Web Control Indonesia 


\section{PENDAHULUAN}

Upaya pemanfaatan energi terbarukan sebagai sumber energi alternatif di Indonesia saat ini telah menjadi prioritas dalam kebijakan energi nasional menurut Peraturan Pemerintah No. 79 tahun 2014 tentang Kebijakan Energi Nasional. Salah satu sumber energi terbarukan yang potensial di Indonesia adalah energi tenaga surya karena Indonesia terletak di garis katulistiwa, yang mempunyai sumber energi surya yang berlimpah dengan intensitas radiasi matahari rata-rata sekitar $4.8 \mathrm{kWh} / \mathrm{m} 2$ per hari di seluruh wilayah Indonesia [1]. Pembangunan pembangkit listrik tenaga surya (PLTS) pada lokasi terpencil atau daerah yang tidak terjangkau grid listrik memberikan banyak potensi pengembangan PLTS namun masih banyak permasalahan pada keberlanjutan operasi dari pembangkit listrik tenaga surya tersebut[2]. Salah satu kendala masalah yang perlu mendapatkan perhatian adalah pada keberlanjutan operasi dari pembangkit listrik tenaga surya (PLTS) yang telah terpasang mengingat instalasi pembangkit tersebut memerlukan biaya investasi yang cukup tinggi. Lokasi pembangkit listrik tenaga surya yang tersebar di daerah terpencil dalam prakteknya menjadi kendala tersendiri dalam hal pemantauan data, kinerja dan kendali pembangkit yang telah terpasang[3]. Pada pembangkit yang dipasang sebagai Concentrated Standalone System, monitoring umumnya dilakukan secara lokal dan tersentral pada pusat pembangkit baik secara manual ataupun otomatis[3]. Monitoring secara manual memiliki kelemahan diantaranya adalah akses parameter, kendali dan data monitoring yang sangat terbatas, tidak lengkap dan tidak kontinu karena keterbatasan operator. Pengamatan yang dilakukan secara lokal oleh operator juga memiliki kelemahan jika unit pembangkit berada pada lokasi yang tersebar didaerah terpencil dan hanya dapat dilakukan dengan mendatangi lokasi pembangkit [4]. Permasalahan yang timbul adalah tidak efisiennya sumber daya manusia jika menempatkan seseorang di lokasi pembangkit listrik tenaga surya (PLTS) jika hanya untuk memantau sistem, karena akan mengeluarkan biaya tambahan dan akan merugikan waktu dan biaya untuk memantau sistem. Selain itu dalam keberlanjutan operasi dari pembangkit listrik tenaga surya (PLTS) ini, penggunaan baterai harus dijaga agar penggunaan optimal sesuai dengan prosedur yang telah ditetapkan oleh pabrikan, yaitu menjaga agar pengisian tidak melebihi kapasitas dan menjaga agar kapasitas baterai tidak berada di bawah kapasitas minimal [5]. Untuk itu perlu adanya suatu sistem yang bisa me-monitoring kinerja PLTS dan mengatur penggunaan aki/baterai secara otomatis, real time dan bisa di pantau dari jarak jauh. Oleh karena itu dengan bantuan mikrokontroller, sensor, dan alat pendukung lainnya, PLTS perlu dilengkapi dengan sebuah sistem monitoring nirkabel berbasis website yang memantau besaran energi pada panel surya, baterai dan beban PLTS. Besaran listrik yang dipantau pada titik-titik pemantauan dikirimkan ke server melalui jaringan internet secara nirkabel menggunakan modul Wi-Fi. Metode Hybrid akan diterapkan untuk mengelompokkan data daya yang dihasilkan panel surya untuk membantu dalam analisa kinerja panel surya serta kemampuan baterai dan pemakaian listrik oleh user. Data daya yang dihasilkan oleh panel surya akan diolah dengan menggunakan atribut jam dan hari/tanggal. Selain itu pada pembangkit dapat dipasang perangkat otomatis yang mampu mendeteksi titik cahaya yang optimal untuk dapat diserap serta mampu mendeteksi kondisi cuaca dilokasi. Untuk itu diperlukan adanya sistem monitoring dan control pada PLTS yang dapat memantau kinerja pembangkit untuk mencegah kerusakan dan penurunan kinerja baterai dan dapat memastikan keberlanjutan operasi dari pembangkit energi surya dengan maksimal mengingat metode Hybrid ini memiliki kemampuan dan akurasi yang baik serta mampu mengadopsi kemampuan pola pikir manusia. 


\section{METODE/PERANCANGAN PENELITIAN}

Tahapan dalam pendekatan masalah dalam penelitian ini digunakan kajian dengan menggunakan beberapa tahapan yang telah dimulai pada periode pertama yang menghasilkan model sistem dan direncanakan selesai dan menghasilkan publikasi ilmiah. Berikut ini adalah gambaran tahapan-tahapan penelitian yang digunakan untuk menyelesaikan masalah yang digambarkan dalam diagram alir menggunakan Fishbone:

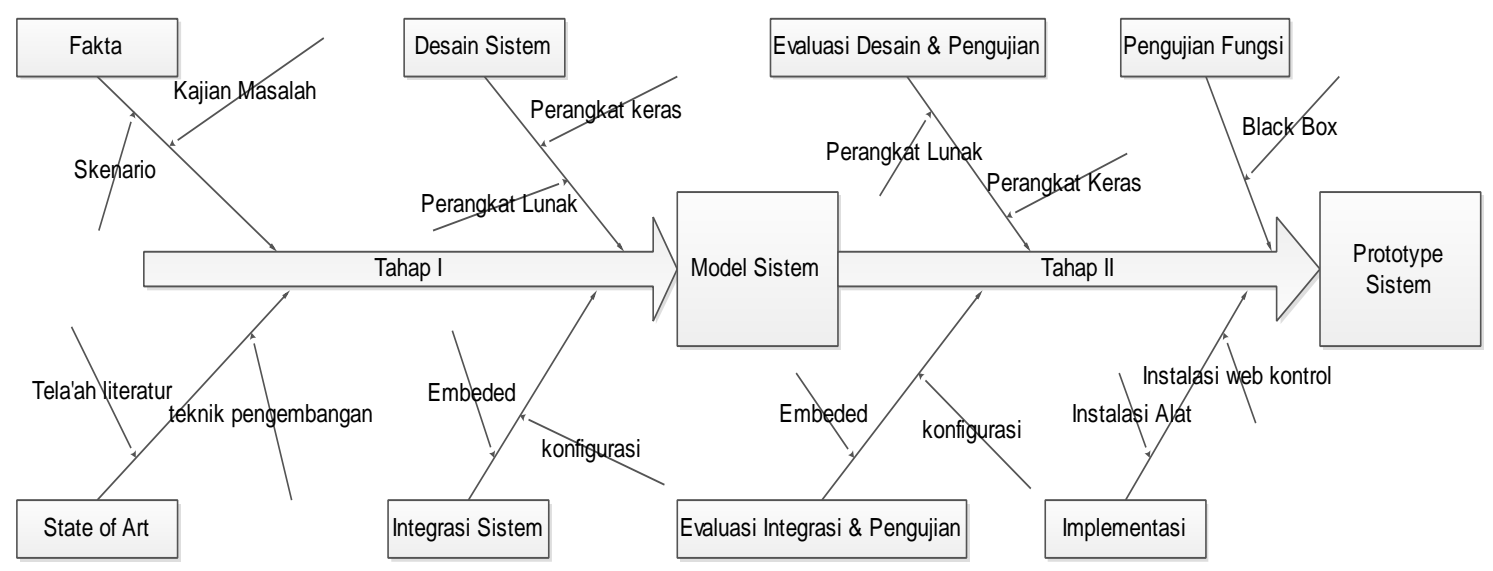

Gambar 1. Diagram Analisa dengan Fishbone

Pada diagram fishbone di atas menggambarkan proses penelitian dan kajian-kajian masalah, melakukan kajian literatur dan desain sistem baik perangkat lunak maupun perangkat keras yang menghasilkan sebuah model system yang telah diuji di laboratorium dengan menggunakan metode uji blackbox yaitu metode uji berdasarkan fungsi dari hasil pengujian tersebut tingkat akurasi mencapai 95 persen berjalan dengan baik dan sesuai dengan yang diharapkan. Dari hasil penelitian tersebut maka akan dilakukan tahap penyempurnaan dari beberapa kekurangannya pada tahapan kedua dan di implementasikan di Desa Ciaruteun Ilir Cibungbulang Bogor Jawa Barat kedepannya. Tahap-tahap yang akan dilakukan adalah :

a. Melakukan evaluasi integrasi model

Pada tahap ini model yang telah dihasilkan dari penelitian sebelumnya akan dilakukan pengujian dan melakukan kajian integrasi perangkat keras dan perangkat lunak yang telah dibuat, Teknik ini dilakukan dengan membagun pembangkit yang real dan dapat diimplentasikan. Pada pembangkit tersebut akan dipasang 4 mikrokontroler yang berfungsi untuk mengendalikan gerak panel surya, memonitor kondisi baterai baik arus yang masuk ataupun keluar dari baterai dan 4 sensor yang berfungsi untuk mendeteksi cuaca serta suhu disekitar pembangkit. Didalam mikrokontroler tersebut akan diprogram dengan menggunakan Algoritma Perceptron agar sensor tersebut dapat mengenali dengan baik kondisi cuaca serta gerak panel surya dapat bergerak sesuai dengan arah matahari secara optimal. Algoritma perceptron akan membaca tiap data yang masuk ke charge controller dan baterai maupun yang keluar dan setiap bobot dari nilai yang masuk akan digunakan Algoritma K-Means untuk menyeleksi bobot yang terbaik agar dapat mengurangi iterasi pembacaan data, cara inilah yang digunakan sebagai Hybrid Method. 
b. Melakukan evaluasi Desain dan pengujian model

Pada tahap ini akan meninjau dan mengevaluasi hasil desain dari penelitian sebelumnya dengan melakukan Analisa model sistem, akurasi aplikasi sampai efektifitas dari jarak jangkau pembangkit dengan aplikasi kontrol. Sebelumnya telah didesain model untuk aplikasinya menggunakan pendekatan Unified modelling Language dan Flowchat System namun perlu dibenahi disesuaikan dengan kondisi nyata dilapangan dan dilakukan pengujian menggunakan User Acceptent Test pengujian ini merupakan pengujian yang dilakukan untuk mengetahui kemampuan alat dan sistem yang dibangun pada kondisi real setalah diimplementasi.

c. Pengujian dan Implementasi

Pada tahap ini pembangkit yang sudah didesain dan aplikasi yang telah dibuat akan diintegrasikan, diinstalasi dan diujikan dengan jarak jangkau antara pembangkit dan lokasi server monitoring lebih kurang $60 \mathrm{KM}$. Pada tahun 2019 merupakan tahap lanjutan dari tahun sebelumnya tahap ini merupakan tahapan melakukan kajian-kajian terhadap Metode Hybrid dengan Artificial Intelligence pada Insatalasi perangkat keras pembangkit. Kajian yang dilakukan adalah dengan menghitung akurasi metode untuk mengenal dan mendeteksi cuaca dan tingkat serapan panel surya terhadap panas matahari. Kemudian melakukan evaluasi hasil pengelompokan data dari pembangkit dengan menggunakan Metode Hybrid. Metode ini merupakan kombinasi Algoritma Perceptron dan K-Means Algorithm. Tahap akhir yang dilakukan adalah melakukan pengujian kembali secara menyeluruh dan menyusun dokumen hasil study kelayakan. Berikut adalah scenario sistem yang dibangun

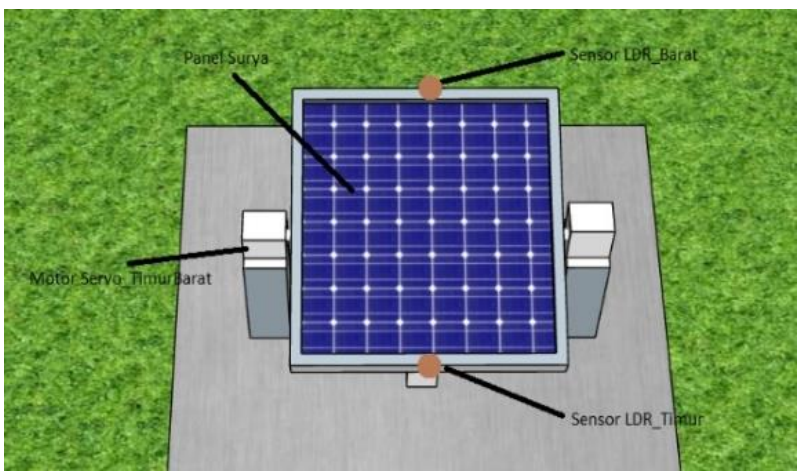

Gambar 2. Arsitektur Teknologi

Konsep teknologi di atas adalah menyerap energi matahari disesuaikan dengan arah datangnya matahari, teknologi di atas akan terintegrasi dengan baterai dan beberapa perangakat elektronik yang dikendalikan. Berikut adalah gambaran keterkaitan dengan perangkat elektronik dan baterai dari panel surya: 


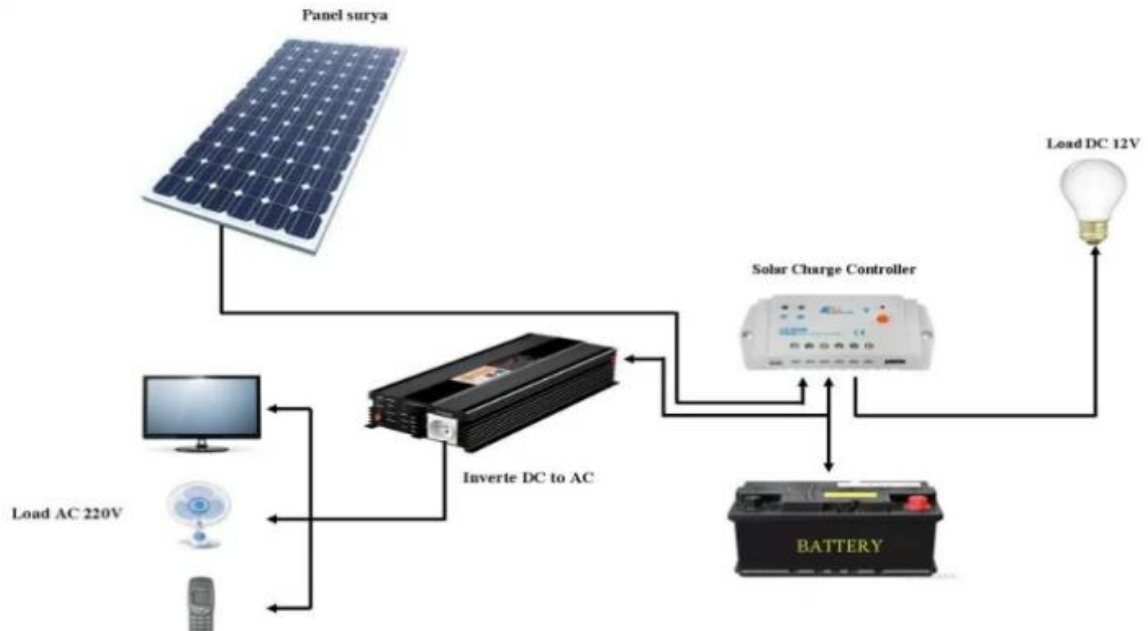

Gambar 3. Arsitektur Teknologi

Untuk sistem kendali dan monitoring akan digunakan website sebagai interface untuk pemampil data dan kendali jauh yang dihosting sehingga dapat diakses melalui jaringan internet. Berikut adalah desain Mikrokontroler dan sensor sebagai penggerak panel surya dan teknologi Kontrol:

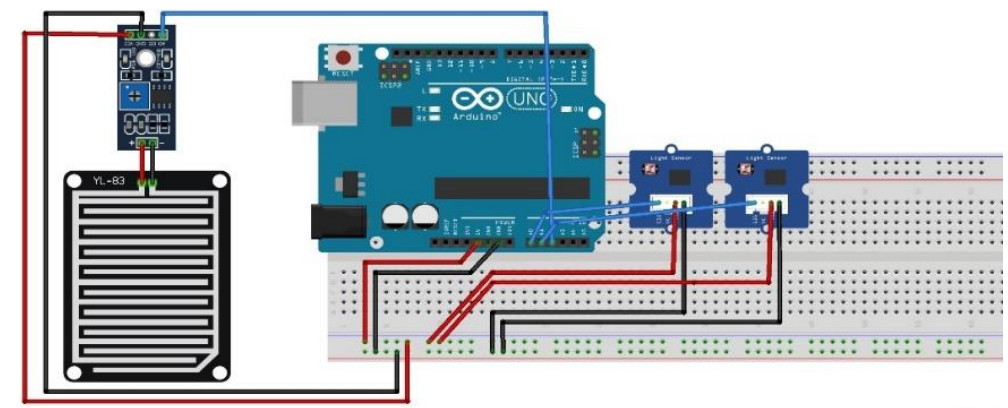

Gambar 4. Rangkaian Kendali dan Monitoring

\section{HASIL DAN PEMBAHASAN}

Dalam menyelesaikan masalah tentang sistem kendali panel surya pada PLTS, menggunakan algoritma jaringan syaraf tiruan model Perceptron untuk membantu dalam menentuan mode penggerak panel surya terhadap sumbu $\mathrm{x}$ (timur-barat). Mode penggerak panel surya terhadap sumbu $\mathrm{x}$ (timu-barat) terdiri dari 2 mode, yaitu: mode 1 pergerakan panel surya dengan kontrol sensor LDR dan mode 2 yaitu pergerakan panel surya dengan kontrol sensor waktu RTC DS3231. Berikut adalah langkah-langkah penyelesaian masalah dengan algoritma jaringan syaraf tiruan Perceptron dari tahap awal hingga tahap akhir adalah seperti berikut :

a. Menentukan parameter-parameter yang akan digunakan dalam proses perceptron, dalam hal ini parameter yang digunakan berupa nilai rata-rata dari sensor LDR dan nilai sensor hujan. Kemudian dilanjutkan dengan penentuan nilai batas untuk menentukan basis pengetahuan (Basic Knowledge) dari parameter yang ada.

b. Menentukan nilai batas untuk parameter nilai rata-rata sensor LDR didapat dari nilai tertinggi pada tabel nilai rata-rata sensor LDR. Empat puluh data pada tabel nilai rata-rata 
sensor LDR kemudian dari hasil tersebut didapati dari hasil pengukuran pada saat kondisi matahari terlihat hingga saat kondisi matahari tertutup awan (mendung \& hujan).

c. Selanjutnya nilai batas untuk parameter nilai sensor hujan didapat dari nilai rata-rata pada tabel nilai sensor hujan. Lima puluh data pada tabel nilai sensor hujan dibawah ini didapati dari hasil pengukuran dengan cara memercikkan air pada permukaan panel sensor dan dimonitoring nilainya per satu detik.

d. Setelah didapatkan penentuan nilai batas untuk parameter nilai rata-rata sensor LDR dan nilai sensor hujan maka didapat basic knowledge sebagai berikut : jika nilai sensor LDR > 19 (matahari tertutup awan) maka bernilai -1 , dan jika nilai sensor LDR $<=19$ (matahari terlihat) maka bernilai 1, jika nilai sensor hujan > 450 (tidak hujan) maka bernilai 1, jika nilai sensor hujan $<450$ (hujan) maka bernilai -1 . Sedangkan nilai target ditetapkan yaitu: jika mode LDR maka bernilai 1 dan jika mode RTC maka bernilai -1.

e. Setelah basis pengetahuan dan target ditentukan dilanjutkan dengan penentuan data training. Data training didapatkan dari hasil pengukuran nilai sensor hujan dan nilai ratarata sensor LDR pada saat kondisi matahari terlihat \& tidak hujan, matahari terlihat \& hujan, matahari tidak terlihat \& tidak hujan, dan matahari tidak terlihat \& hujan. Yang kemudian akan dijadikan sebagai unit inputan perceptron dengan target yang diinginkan

Tabel 1. Unit Masukan Perceptron

\begin{tabular}{cccc}
\hline$x_{1}$ & $x_{2}$ & 1 & Target \\
\hline 1 & 1 & 1 & 1 \\
1 & -1 & 1 & -1 \\
-1 & 1 & 1 & -1 \\
-1 & -1 & 1 & -1 \\
\hline
\end{tabular}

f. Kemudian dilakukan proses pelatihan perceptron yang dimulai dari inisialisasi semua bobot dan bias, umumnya $w_{-} i=b=0$ (Siang, 2005). kemudian tentukan laju pemahaman $(\alpha)$, untuk penyederhanaan biasanya $\alpha$ diberi nilai $=1$. Dan diketahui juga $\theta$ (threshold $)=0$, sehingga fungsi aktivasi menjadi:

$$
y=f(n e t)=\left\{\begin{array}{cc}
1 & \text { jika net }>\theta \\
0 & \text { jika net }=\theta \\
-1 & \text { jika net }<-\theta
\end{array}\right\}
$$

g. Iterasi untuk seluruh pola yang ada disebut epoch. Tabel dibawah ini menunjukkan hasil pada epoch pertama:

Tabel 2. Epoch Pertama Pelatihan Perceptron

\begin{tabular}{ccccccrrrrrr}
\hline & \multirow{2}{*}{$x_{1}$} & 1 & target & \multirow{2}{*}{ net } & $y=f($ net $)$ & \multicolumn{4}{c}{ Perubahan } & \multicolumn{4}{c}{ Bobot Baru } \\
& & & & & & $\Delta w_{1}$ & $\Delta w_{2}$ & $\Delta b$ & $w_{1}$ & $w_{2}$ & $b$ \\
\hline 1 & 1 & 1 & 1 & 0 & 0 & 1 & 1 & 1 & 1 & 1 & 1 \\
1 & -1 & 1 & -1 & 1 & 1 & -1 & 1 & -1 & 0 & 2 & 0 \\
-1 & 1 & 1 & -1 & 2 & 1 & 1 & -1 & -1 & 1 & 1 & -1 \\
-1 & -1 & 1 & -1 & -3 & -1 & 0 & 0 & 0 & 1 & 1 & -1 \\
\hline
\end{tabular}


Pada input pertama $\left(x_{1}, x_{2} 1\right)=\left(\begin{array}{lll}1 & 1 & 1\end{array}\right)$. Harga net dihitung berdasarkan bobot yang sudah ada sebelumnya yaitu $\left(w_{1} w_{2} b\right)=\left(\begin{array}{lll}0 & 0 & 0\end{array}\right)$. Maka net $=\sum x_{i} w_{i}+b=1(0)+$ $1(0)+0=0$ sehingga $f($ net $)=f(0)=0$. Keluaran jaringan $(f($ net $)=0)$ tidak sama dengan target yang diinginkan (dalam iterasi ini adalah 1), maka bobot diubah menggunakan rumusan $\Delta w=\alpha t x_{i}=t x_{i}$ (karena $\left.\alpha=1\right)$. Bobot baru $=$ bobot lama + $\Delta w$. Input pola kedua dan seterusnya dihitung secara analog. Pada pola terakhir $\left(x_{1}, x_{1} 1\right)=(-1-11)$, harga $f($ net $)=-1$ yang sama dengan targetnya. Maka bobot tidak diubah. Hal ini dinyatakan dengan kondisi $\Delta w=0$.

h. Mengingat tidak semua $f(n e t)$ pada epoch pertama sama dengan target $(t)$, maka iterasi dilanjutkan pada epoch kedua. Semua pola kembali demasukkan ke jaringan dengan menggunakan bobot terakhir yang diperoleh sebagai bobot awalnya. Diperoleh hasil iterasi seperti tabel di bawah ini:

Tabel 3. Epoch Kedua Pelatihan Perceptron

\begin{tabular}{cccccccrrrrrr}
\hline \multirow{2}{*}{$\boldsymbol{x}_{\mathbf{1}}$} & $\boldsymbol{x}_{\mathbf{2}}$ & $\mathbf{1}$ & \multirow{2}{*}{ target } & \multirow{2}{*}{ net } & $\boldsymbol{y}=\boldsymbol{f}(\boldsymbol{n e t})$ & \multicolumn{3}{c}{ Perubahan } & \multicolumn{3}{c}{ Bobot Baru } \\
& & & & & & $\Delta \boldsymbol{w}_{\mathbf{1}}$ & $\Delta \boldsymbol{w}_{\mathbf{2}}$ & $\Delta \boldsymbol{b}$ & $\boldsymbol{w}_{\mathbf{1}}$ & $\boldsymbol{w}_{\mathbf{2}}$ & $\boldsymbol{b}$ \\
\hline 1 & 1 & 1 & 1 & 1 & 1 & 0 & 0 & 0 & 1 & 1 & -1 \\
1 & -1 & 1 & -1 & -1 & -1 & 0 & 0 & 0 & 1 & 1 & -1 \\
-1 & 1 & 1 & -1 & -1 & -1 & 0 & 0 & 0 & 1 & 1 & -1 \\
-1 & -1 & 1 & -1 & -3 & -1 & 0 & 0 & 0 & 1 & 1 & -1 \\
\hline
\end{tabular}

Dalam iterasi tersebut, untuk semua pola nilai $f($ net $)=t$ sehingga tidak dilakukan perubahan bobot. Karena $f(n e t)=t$ untuk semua pola maka jaringan sudah mengenal semua pola sehingga iterasi dihentikan.

i. Setelah didapatkan nilai bobot akhir dari proses pelatihan perceptron yaitu: $w_{1}=1, w_{2}=$ $1, b=-1$ maka dilanjutkan ke proses pengujian data untuk pemilihan mode pergerakan panel surya sumbu x (timur-barat). Pengujian data dilakukan dengan memasukkan nilai yang dihasilkan oleh sensor hujan dan sensor LDR ke rumus respon unit keluaran $\left(\sum x_{i} w_{i}+b\right)$ dan kemudian di bandingkan dengan fungsi aktivasi untuk melihat hasil $y=$ $f(n e t)$, sehingga dapat dihasilkan pemilihan mode pergerakan berdasarkan LDR $(\mathrm{y}=1)$ atau RTC $(\mathrm{y}=-1)$

\section{KESIMPULAN DAN SARAN}

Dari hasil penelitian yang dilakukan dari tahap awal hingga proses pengujian, dengan adanya sistem kendali panel surya pada PLTS ini dapat disimpulkan bahwa:

1. Sistem kendali panel surya pada PLTS ini menggunakan sensor LDR(Light Depenedent Resistor) dan modul RTC DS3231 yang dikombinasikan dengan motor penggerak (Motor Servo) sebagai output untuk memposisikan panel surya agar selalu tegak lurus dengan arah matahari.

2. Sistem kendali panel surya dapat bergerak terhadap sumbu $x$ (timur-barat) dan sumbu y (utara-selatan).

3. Pergerakan panel surya terhadap sumbu x (timur-barat) memiliki 2 mode yang switch otomatis bergantung keadaan lingkungan sekitar (hujan dan berawan). 2 mode itu adalah mode pergerakan panel surya berdasarkan sensor LDR dan mode pergerakan panel surya berdasarkan modul RTC. 
4. Pergerakan panel surya terhadap sumbu y (utara-selatan) bergerak dengan berdasarkan waktu yaitu mode RTC.

5. Pemilihan mode pergerakan sumbu $\mathrm{x}$ (timur-barat) didapat dari hasil perhitungan algoritma perceptron dengan unit masukan dari sensor LDR dan sensor Hujan. Setelah dilakukan pengujian validasi algoritma perceptron menggunakan metode $M A P E$, hasil yang didapati yaitu nilai akurasi dengan menggunakan algoritma perceptron sebesar 100\% dengan nilai error yang didapatkan adalah $0 \%$.

6. Sistem kendali panel surya pada PLTS ini telah sesuai dengan rancangan yang diinginkan berdasarkan hasil penilaian oleh dosen pembimbing dengan metode pengujian black box dan observasi dilapangan selama 2 hari dengan hasil efisiensi penyerapan energi oleh panel surya dengan sistem kendali sebesar 59,5\% sedangkan panel surya tanpa sistem kendali sebesar 49,6\% dari total maksimum daya yang mampu dihasilkan oleh panel surya $10 \mathrm{Wp}$.

Dalam penelitian ini menghasilkan desain sistem dan penerapan algoritma-algoritma sistem komputasi cerdas namun perlu dikembangkan dan diuji untuk mendapatkan hasil yang optimal, selain itu dari hasil rancangan ini perlu di buat model atau prototype agar dapat divisualisasi dan dapat uji pada lingkungan yang sebenarnya. Harapanya hasil akhir dari penelitian ini dapat di kembangkan dan di implementasi pada lingkungan yang sesungguhnya dan dijadikan acuan dalam penyusunan kurikulum pada matakuliah yang terkait dengan sistem komputasi.

\section{UCAPAN TERIMAKASIH}

Terima kasih yang tak terhingga kepada Insitut Teknologi PLN yang telah memberikan dukungan baik dalam bentuk materi dan moril kepada kami sehingga penelitian dapat terlaksana juga tak lupa kami ucapkan kepada Lembaga penelitian Institut Teknologi PLN yang secara teknis telah membantu dan telah mengarahkan kami sehingga penelitian ini dapat berjalan dengan baik dan orang-orang yang telah berkontribusi dalam penelitian ini seperti keluarga yang telah meberikan motivasi yang luar biasa serta para mahasiswa yang telah membantu dalam pengumpulan data.

\section{DAFTAR PUSTAKA}

[1] G. Pikra, A. Salim, B. Prawara, A. J. Purwanto, T. Admono, and Z. Eddy, "Development of small scale concentrated solar power plant using organic Rankine cycle for isolated region in Indonesia," Energy Procedia, vol. 32, pp. 122-128, 2013.

[2] A. Haris and E. Hendrian, "Sistem Monitoring dan Klaster Ketersediaan Energi Menggunakan Metode K-Means pada Pembangkit Listrik Tenaga Surya,” vol. 4, no. 2, pp. 266-271, 2019.

[3] P. C. Siswipraptini, R. Nur Aziza, I. B. M. Sangadji, I. Indrianto, and R. R. A. Siregar, "Automated Smart Home Controller Based on Adaptive Linear Neural Network," 2019 IEEE 7th Int. Conf. Control. Mechatronics Autom. ICCMA 2019, pp. 423-427, 2019.

[4] Siregar RR, Sikumbang H, Sangadji IB. KWh Meter Smart Card Model Token For Electrical Energy Monitoring. InMATEC Web of Conferences 2018 (Vol. 218, p. 03002). EDP Sciences.

[5] A. Wisnu, W. Nugraha, I. Rosyadi, J. T. Elektro, and U. J. Soedirman, "Jte - itp issn no. 22523472 desain sistem monitoring nirkabel berbasis website untuk pemantauan baterai dan beban pembangkit listrik hibrida surya - angin," Winasis*, Azis Wisnu Widhi Nugraha, Imron Rosyadi Jur., vol. 5, no. 2252, pp. 137-142, 2016.

[6] Siregar RR, Sikumbang H, Pasaribu RJ. Model Pengisian Pulsa Listrik Kwh Meter Dengan Smart Card. Jetri: Jurnal Ilmiah Teknik Elektro. 2018 Aug 15;16(1):39-54. 
[7] Handoko, "Solar Power Monitoring System Based On ATMEGA16 Microcontroller And Teamviewer," J. Tek. dan Ilmu Komput., vol. 06, no. 21, pp. 9-16, 2016.

[8] Prianty AF, Siregar RR, Arianto R. Penanganan Gangguan Listrik Rumah Tangga Menggunakan Algoritma Greedy Untuk Penentuan Jarak Optimal. JURNAL TEKNOLOGIA. 2019 Aug 9;2(1).

[9] Nisa TC, Siregar RR, Suliyanti WN. Estimasi Daya Beban Listrik Pada Gardu Induk Cengkareng Dengan Menggunakan Metode Time Series Model Dekomposisi. Jurnal Teknologia. 2019 Apr 7;1(2).

[10] Sangadji I, Arvio Y. Dynamic Segmentation Of Behavior Patterns Based On Quantity Value Movement Using Fuzzy Subtractive Clustering Method. InJournal of Physics: Conference Series 2018 Mar 1 (Vol. 974, No. 1, p. 012009). IOP Publishing.

[11] Siregar RR, Siregar ZU, Arianto R. Klasifikasi Sentiment Analysis Pada Komentar Peserta Diklat Menggunakan Metode K-Nearest Neighbor. KILAT. 2019 May 17;8(1).

[12] Arvio Y, Sangadji IB, Sikumbang H, Anjarwati MD. Pendekatan Implementasi Model Substractive Clustering Dalam Memetakan Dan Klasifikasi Data Perilaku Konsumen Listrik Tegangan Rendah Studi Kasus: Pelanggan PT PLN (Persero) UP3 Cengkareng. PETIR: Jurnal Pengkajian dan Penerapan Teknik Informatika. 2019 Sep 25;12(2):251-61.

[13] Siregar RR, Wardana N, Luqman L. Sistem Monitoring Kinerja Panel Listrik Tenaga Surya Menggunakan Arduino Uno. Jetri: Jurnal Ilmiah Teknik Elektro. 2017 Feb 23;14(2):81-100.

[14] Haris A. Penerapan Metode Fuzzy Tsukamoto untuk Menentukan Kualitas Proposal Layak Hibah. Faktor Exacta. 2019 May 14;12(1):1-8.

[15] Haris A. Sistem Pencatat Kwh Meter Terintegrasi Komputer Untuk Meningkatkan Layanan Pada Pelanggan. Kilat. 2017;6(1):22-7. 